\title{
THE BIOEROSION OF VERTEBRATE TISSUES
}

DAVIS*, Paul G., Department of Geology, Wills Memorial Building, University of Bristol, Queens Road, Bristol, Avon BS8 1RJ. ENGLAND.

Bioerosion is the abrasion of hard substrates through the activity of organisms. This study presents a synthesis of modern, archaeological, and palaeontological bioerosion of vertebrate tissue.

It describes the first evidence for the bioerosion of modern, archaeological and fossil bird bones. In addition a new form of bone bioerosion, known as Hackett tunnels, is identified. The bioerosion of vertebrate tissue by cyanobacteria and algae in modern marine and lacustrine environments is also described. Archaeological evidence indicates that the destruction of bone, by bioerosion, occurs in other environments such as cave deposits and middens.

Bone that appears to be macroscopically well preserved can have large amounts of microscopic fabric destruction. The rate and speed of this destruction is controlled by environmental factors such as temperature, water depth, sunlight, current strength and salinity.

Bioerosion can minic the effects of mechanical transport. Thus careful taphonomic analysis must be completed before transport is cited as the cause of bone destruction.

Bioerosion causes loss of information. This information loss from the archaeological/geological record is higher than previously thought and can occur in environments where good preservation is normally expected. 